\title{
THE EFFECT OF INJECTION OF INTRA ARTICULAR ALLOGENIC BONE MARROW MESENCHYMAL STEM CELL-PLATELET CELL RICH PLASMA (BMSCs-PRP) ON FULL-THICKNESS ARTICULAR CARTILAGE DEFFECT REGENERATION IN RABBIT
}

\author{
S. Ahmad Taufik ${ }^{1}$, Dwikora Novembri Utomo ${ }^{1,2}$ \\ ${ }^{1}$ Department of Orthopaedic, Faculty of Medicine, Airlangga University -Dr. Soetomo Hospital, \\ Surabaya, Indonesia. \\ ${ }^{2}$ Stem Cell Research and Development Center, Universitas Airlangga Surabaya, East Java, Indonesia.
}

\begin{abstract}
The joint cartilage defectfulthickness is still a problem today because its currenttreatment still has not delivered maximum results. Current treatment uses cartilage enginering using mesenchymal stem cells alone and or combining growth factor. The aim of this study was to investigate the effect of intra-articular injection of Allogenic bone marrow mesenchymal stem cell - Platelet rich plasma (BMSCs-PRP) on regeneration of cartilage defect fullthickness in rabbits. The design of this study was a post-test only control group design using 36 New Zealand white rabbits divided into three groups. Each group were treated with PRP, BMSCs and BMSCs-PRP. Results were evaluated after 10 weeks. In the evaluation, macroscopic images showed the best healing in the BMSCs-PRP group. Histopathologic examination showed that in the MSCs-PRP group, there was a significant increase in the number of chondrocytes $(\mathrm{p}=0,000)$, cartilage area $(\mathrm{p}=0,000)$, as well as the number of Agecoprogenitorexpec- tion cells $(p=0,000)$ and collagen type $2(p=0,000)$. BMSCs were able to differentiate into condroblasts which then synthesize aggressive and collagen type 2. Platelet rich plasma (PRP) contains growth factor BMP, TGF, FGF and IGF which can accelerate the occurrence of MSCs differentiation. Intra-articular injections Allogenic bone marrow mesenchymal stem cell (BMSCs-PRP) is able to regenerate and cure full-thickness joint cartilage defects through differentiation of MSCs into condroblasts.
\end{abstract}

Keyword: Allogenic, Bone marrow Mesenchymal stem cell, Cartilage, Platelet rich plasma, Fullthickness.

\section{INTRODUCTION}

Cartilage of joints is an important part of the joint component. Damage to joints often occurs in sports activities, where some studies show nearly $49 \%$ of joint damage are due to sports injuries (Aroen et al., 2004). Its high ability to hold and absorb weight is helpful in resisting the mechanical forces acting on joints during sports activities (Williams et al., 2007).
Cartilage joints are perfect for network engineering applications because of its properties.

Cartilage of joints is an important part of the joint component. Damage to joints often occurs in sports activities, where some studies get nearly $49 \%$ of joint damage occurring due to sports injuries (Aroen et al., 2004). Its high ability to hold and absorb weight is helpful in 
resisting the mechanical forces acting on joints during sports activities (Williams et al., 2007). Cartilage joints are particularly suitable for tissue engineering applications due to their avascular, aneural and alymphatic properties (Khan and Hardingham, 2007). The affected cartilage of the affected joints shows limited healing ability. Damage to joint cartilage that affects the subchondral bone shows signs of healing due to the release of bone marrow mesenchymal stem cells (BMSCs). This is the principle of microfracture (Punwar and Khan, 2011).

Generally mesenchymal stem cells implanted in joint cartilage defects are included in the three-dimensional scaffold. Some issues relating to the use of scaffolds are material selection, the ability to support cell viability and differentiation, retention and degradation problems at the site. Injection of intra-articular MSCs has been performed with satisfactory results on the regeneration of meniscus with osteoarthritis in the caprine model. Injection of MSCs in joints is focused by using carrier scaffold to localize MSCs at the site of the defect. Injection of MSCs with solvent fluid facilitates migration and attachment of MSCs to the site of the defect. Various materials are used as carriers such as hydrogel, fibrin matirx and hyaluronic acid (McIlwraith et al., 2011).

\section{METHODS}

This research was true experimental research with post test only control group design. In this study, there were no control treatments, no replication, and randomization.
Platelet rich plasma (PRP) has been used as a treatment for cartilage damage joints. In PRP found platelets with high concentrations. PRP is not immunogenic, can be absorbed by the body (bioabsorbable), sterile, easily prepared and applied to the patient. Platelets consist of $\beta$-secretory granules containing transforming growth factor (TGF) -1 , insulin growth factor (IGF) and platelet derived growth factor (PDGF) that can stimulate joint cartilage regeneration (Chen et al., 2007).

Currently, there is no study that combined allogenic MSCs and PRPs in cartilage defects, whereas either MSCs or PRP itself has been shown to have a positive effect on cartilage regeneration. Giving PRP to MSCs cultures can increase in vitro proliferation and tendency to increase MSCs differentiation into chondroblasts and osteoblasts (Getgood, 2009). Allogenic MSCs can improve cartilage regeneration and do not cause autoimmune rejection reactions. MSCs have immunosuppressive syphles that allow them to be used allogenically (Caplan AI and Dennis JE, 2006). In this study, we investigated the effect of intra-articular injection of allogenic bone marrow mesenchymal stem cell-rich plasma platelet (BMSCs - PRP) to the regeneration of full-thickness joint cartilage defect in rabbits.

The experimental unit was divided into three different treatment groups, then evaluated after 10 weeks. This research was conducted for 6 months from May 2014 - October 2014 at Airlangga University's Stem Cell Research and 
Development Center Laboratory, Central Installation of Biomaterials and Tissue Bank of RSUD Dr. Sutomo, Integrated Electron Microscope Laboratory Medical Faculty of

\section{RESULTS}

\section{Results of research on in vitro}

Isolation, culture and expansion of Bone Marrow Mesenchymal stem cells (BMSCs). To obtain sufficient amount of BMSCs for
Universitas Airlangga, Anatomical Pathology Laboratory, Integrated Diagnostic Center RSUD Dr. Soetomo, Surabaya.

injection 2 x 107 was done culture for 2 weeks. This amount is reached on passage 3 . The optimal number of BMSCs for mobilization to the defect in a rabbit knee is $1 \times 107$ per $\mathrm{mL}$.
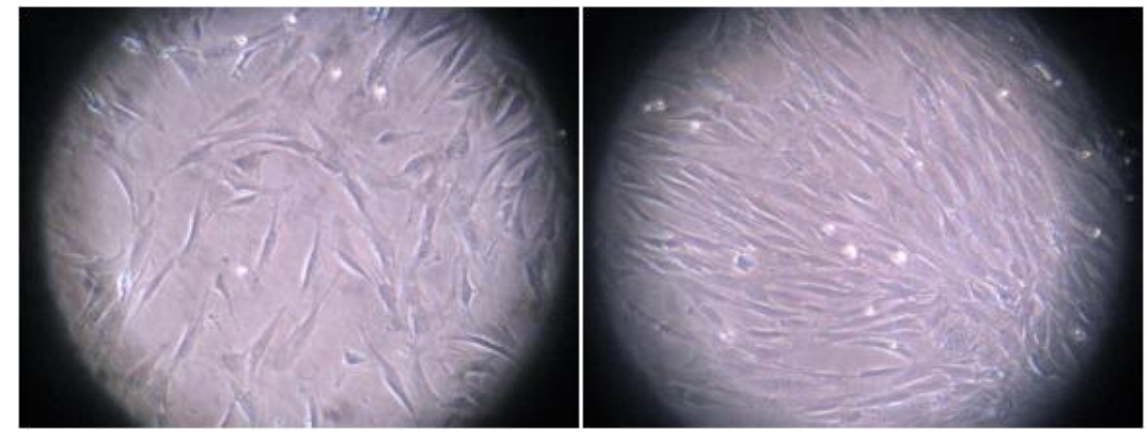

Figure 1. A. Bone marrow BMSCs has reached $40 \%$ confluent, neutral filter without staining, B. BMSCs has reached $70 \%$ confluent, netral without staining microscope filter

\section{The results of Platelet Rich Plasma (PRP)}

The making of platelet-rich plasma (PRP) was performed with two revolutions of 3000 rpm for 13 minutes at 1 and $3000 \mathrm{rpm}$ for 15 minutes at stage 2 . The final result of $20 \mathrm{ml}$ of

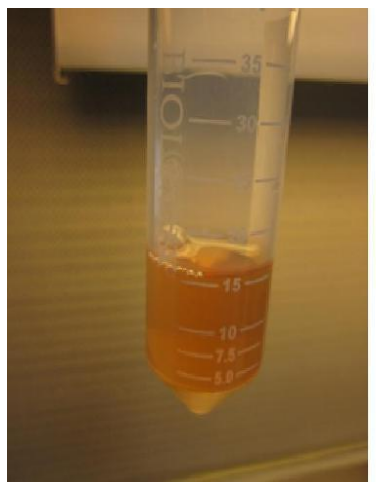

Figure 2. The process of making the PRP. A. Result of centrifuge stage 1.B.Result centrifuge stage 2.

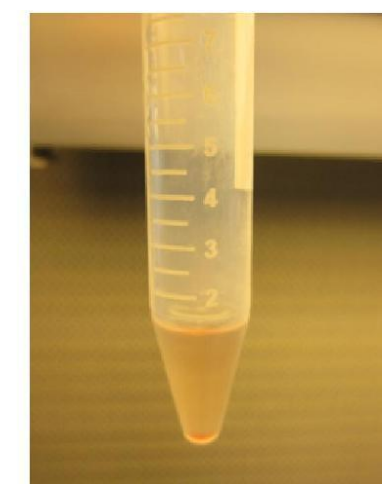

peripheral blood taken then processed was $2 \mathrm{ml}$ PRP. It was found that the number of RPP was 5 times the number of platelets in peripheral blood. 
The results of macroscopic examination cartilage of the knee joint of rabbits

After sacrifice at the $10^{\text {th }}$ week in the was almost invisible. The defect area was filled with experimental animal then took the knee joint that the same whitish cartilage tissue with the color of the received the injection BMSCs-PRP. Macroscopically surrounding cartilage. The boundary of the healing in the evaluation of defects in groups receiving the region with its surrounding was not clear with the platelet-rich plasma (PRP) and Bone marrow same surface height as its surroundings. This shows mesenchymal stem cells (BMSCs). Visible healing the best healing in the BMSCs-PRP group. defects in BMSCs, although not all closed. The Comparison of microscopic display of each defect had been filled with a whitish cartilage treatment.

network where the boundary with healthy tissue was still visible. The healing surface of the healing tissue in the defect is also lower than the surrounding healthy tissue. In the knee joint group who received PRP the visible defect clearly. The defects were still
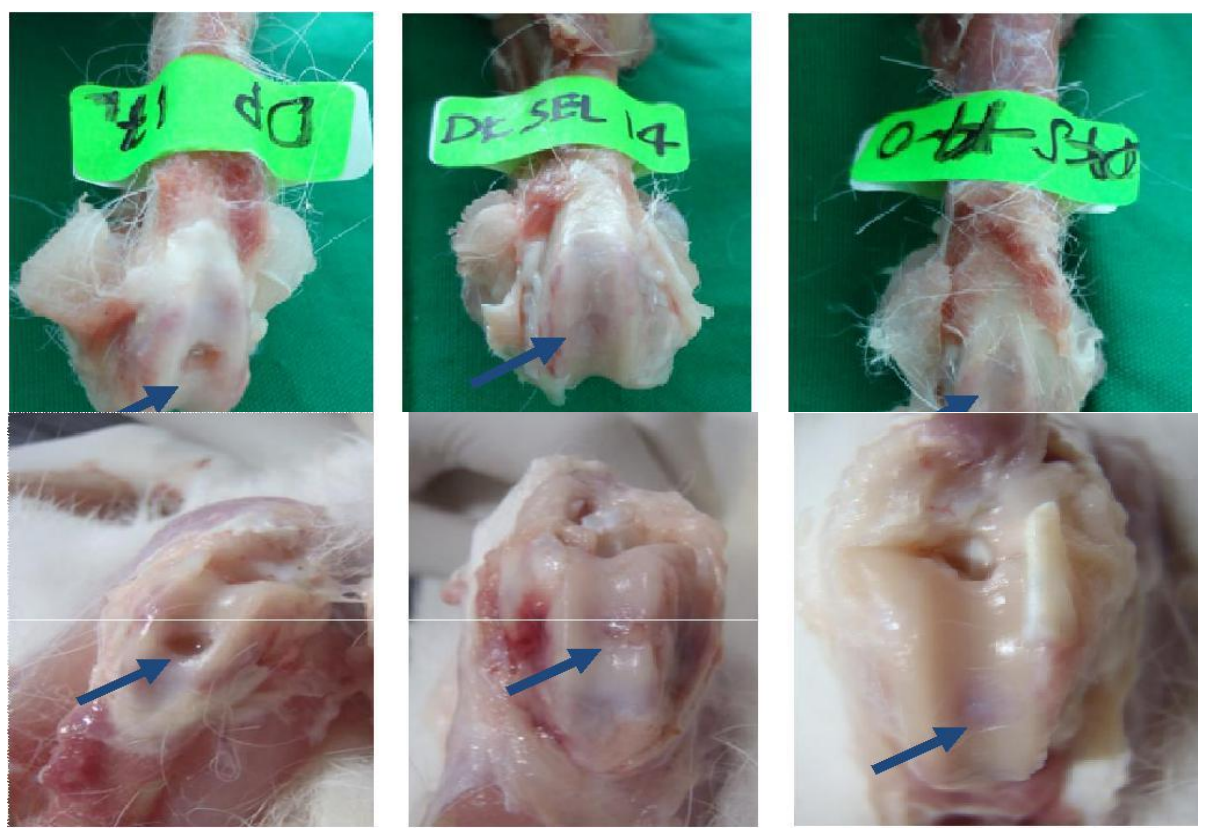

Figure 3. Overview macroscopicdefects cartilage jointafter 10 weeks. A. Injection of PRP. B. Injection with BMSCs. C. Injection of PRP BMSCs-PRP 


\section{Histological examination results}

Total chondrocytes

Table 1 shows the difference in number of chondrocytes, highest in BMSCs-PRP group and lowest in the PRP group. Average number of chondrocytes in the PRP group was $6.1 \mathrm{x}$ $10^{4}$ whereas in BMSCs-PRP group was $2.5 \mathrm{x}$ $10^{5}$.

Table 1 Number of Condrocytes in treatment group PRP, BMSCs dan BMSCs-PRP

\begin{tabular}{|c|c|c|c|c|c|c|}
\hline \multirow{2}{*}{ Group } & \multirow{2}{*}{$\mathrm{n}$} & \multicolumn{4}{|c|}{ Number of Condrocytes } & \multirow{2}{*}{$\begin{array}{l}\text { Anova one- } \\
\text { way Statistic }\end{array}$} \\
\hline & & $\overline{\mathrm{x}}$ & $\mathrm{sd}$ & $\min$ & $\max$ & \\
\hline PRP & 10 & $60655,28^{\mathrm{a}}$ & 17058,28 & 34320,3 & 86435,3 & \\
\hline BMSCs & 11 & $130870,44^{\mathrm{b}}$ & 26593,54 & 87645,5 & 174543,5 & Stat : 8,82 \\
\hline $\begin{array}{l}\text { BMSCs- } \\
\text { PRP }\end{array}$ & 11 & $247157,93^{\mathrm{c}}$ & 26834,91 & 198648,4 & 286842,4 & $\mathrm{P}=0,000^{*}$ \\
\hline
\end{tabular}

Note : Significant $\alpha=0,05$

${ }^{\mathrm{a}, \mathrm{b}, \mathrm{c}}$ The different superscript show the difference between group (based on multiple comparison LSD)

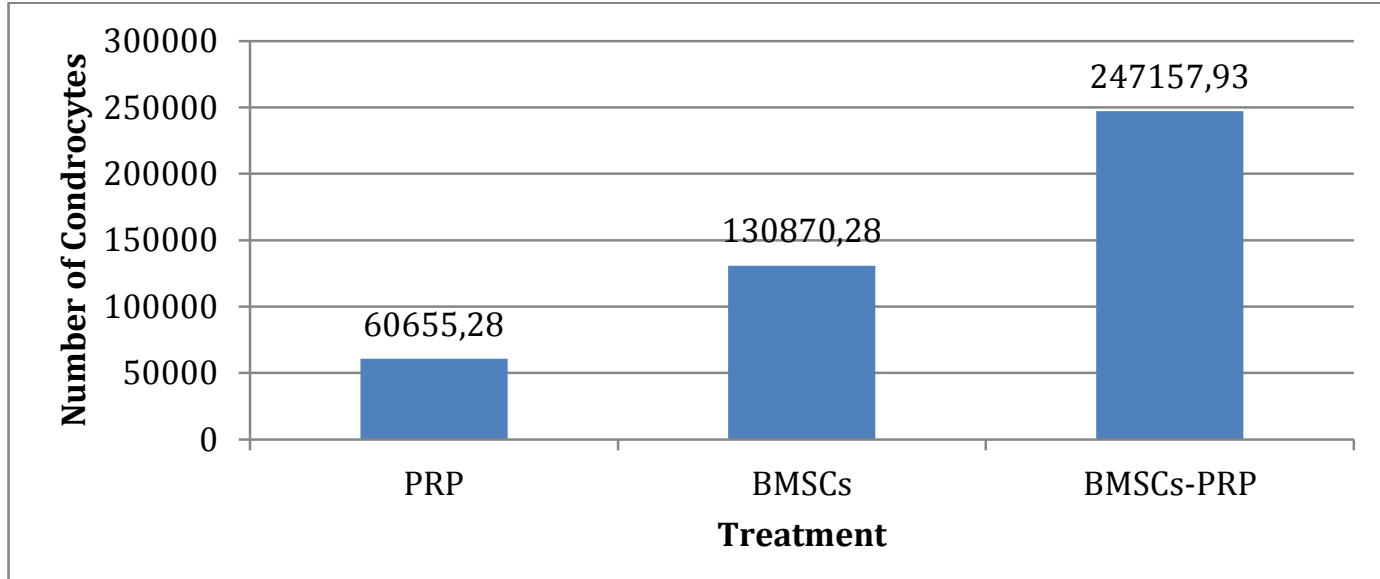

Figure 4. Comparison number of chondrocytes in the three treatment groups

Width Cartilage

Table 2 shows the difference in width cartilage, highest in BMSCs-PRP group and lowest in the PRP group. Width cartilage in the BMSCs-PRP group was $2,4 \times 10^{5}$, whereas in $\begin{array}{llllll}\text { PRP group was } & 8,2 & \text { x } & 10^{4}\end{array}$

Table 2. Luas cartilage pada kelompok perlakuan PRP, BMSCs dan BMSCs-PRP

\begin{tabular}{c|l|c|c|c|c|c}
\hline \multirow{2}{*}{ Groups } & \multirow{2}{*}{$\mathrm{N}$} & $\overline{5}$ & SD & Min & Maks & $\begin{array}{c}\text { Brown- } \\
\text { Forsythe } \\
\text { Statistic }\end{array}$ \\
\cline { 3 - 6 } & & & $\overline{\mathrm{x}}$ & & & \\
\hline PRP & 10 & $82774,33^{\mathrm{a}}$ & 10834,22 & 45456,81 & 77348,74 & Stat $=3,755$ \\
BMSCs & 11 & $142955,27^{\mathrm{b}}$ & 26894,92 & 108826,5 & 186354,64 & $\mathrm{p}=0,000^{*}$ \\
\hline BMSCs-PRP & 11 & $244646,56^{\mathrm{c}}$ & 21100,28 & 213731,2 & 278654,36 & \\
\hline
\end{tabular}

Description: * significant at $\mathrm{a}=0.05$

$\mathrm{a}, \mathrm{b}, \mathrm{c}$ of different superscript indicate a difference between groups (based on multiple comparisons Games-Howell) 


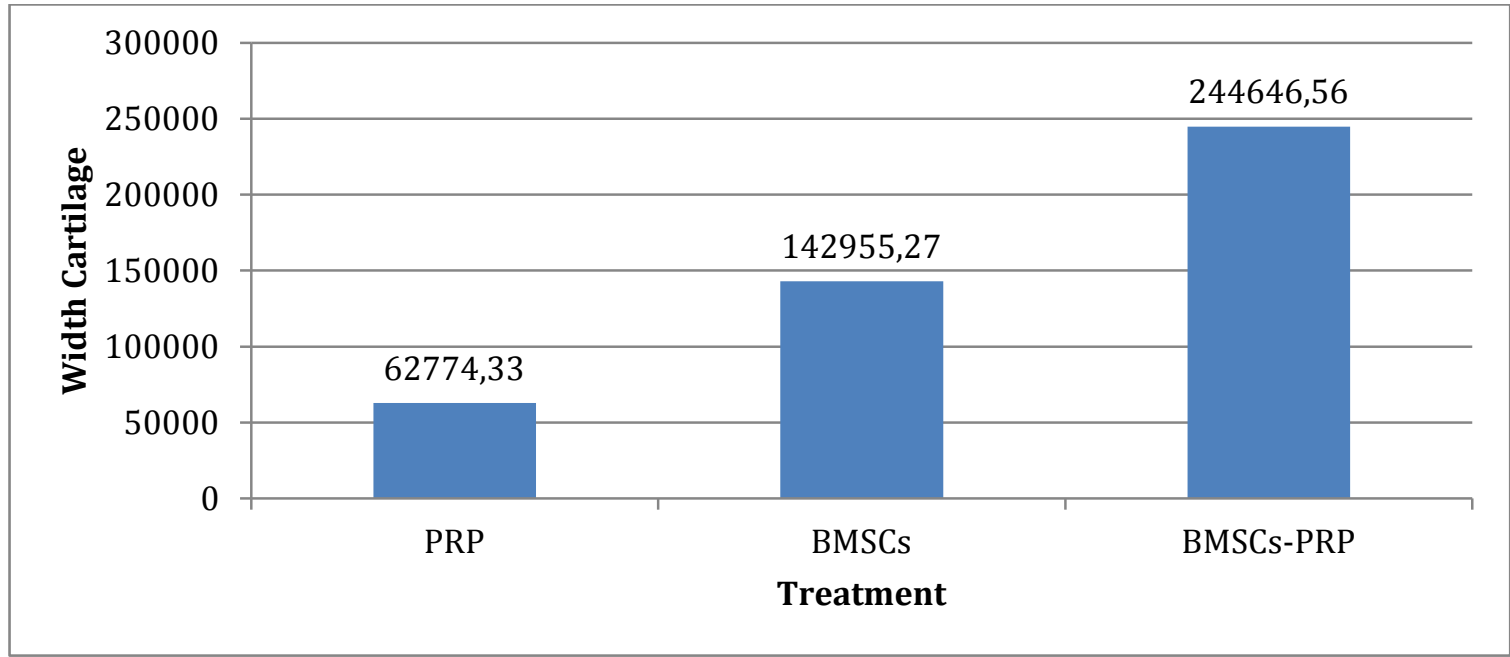

Figure 5. Comparison of the cartilage area in the three treatment groups

Immunohistochemical results

Number of agrecan expression cells

Table 3 shows the difference in the number of
BMSCs-PRP group and slightly in the PRP group. The number of cells in the BMSCs-PRP group was $24.9 \%$, whereas the PRP group was $2.7 \%$.

Agrecan expression cells, mostly in the

Table.3. Percentage of Agrecan in the treatment group PRP, BMSCs and BMSCs-PRP

\begin{tabular}{|c|c|c|c|c|c|c|}
\hline \multirow[b]{2}{*}{ Group } & \multirow[b]{2}{*}{$\mathrm{N}$} & \multicolumn{4}{|c|}{ Arecan (\%) } & \multirow{2}{*}{$\begin{array}{l}\text { Brown- } \\
\text { Forsythe } \\
\text { Statistics }\end{array}$} \\
\hline & & $\overline{\mathrm{x}}$ & SD & Min & $\operatorname{Max}$ & \\
\hline PRP & 10 & $2,70^{\mathrm{a}}$ & 0,63 & 1,65 & 3,67 & stat $=$ \\
\hline BMSCs & 11 & $9.77^{\mathrm{b}}$ & 1.14 & 8.64 & 12.31 & $8.81, p=$ \\
\hline BMSCs-PRP & 11 & $24.90^{\mathrm{c}}$ & 2.32 & 21.12 & 28.54 & $0.000 *$ \\
\hline
\end{tabular}

Note: $*$ significant at a $=0.05$

a, b, c of different superscript shows the difference between groups (based on multiple comparisons Games-Howell)

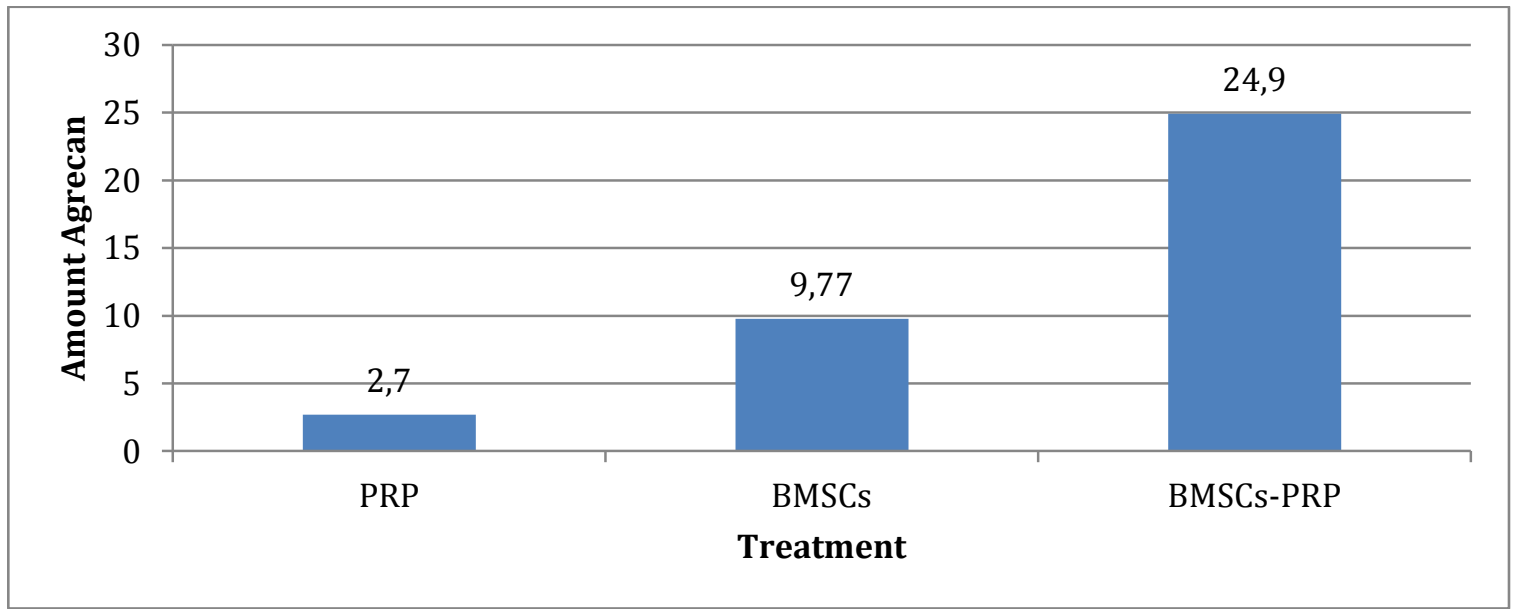

Figure 6. Comparison of the number Agrecan in the three treatment groups

Figure 6 shows the percentage of Agrecan in each treatment group. The results of analysis by Brown-Forsythe Statistic p value $=0.000$ which means there is a significant difference 
between the number of cells expression

PRP.

Agrecan the PRP group, BMSCs and BMSCs-
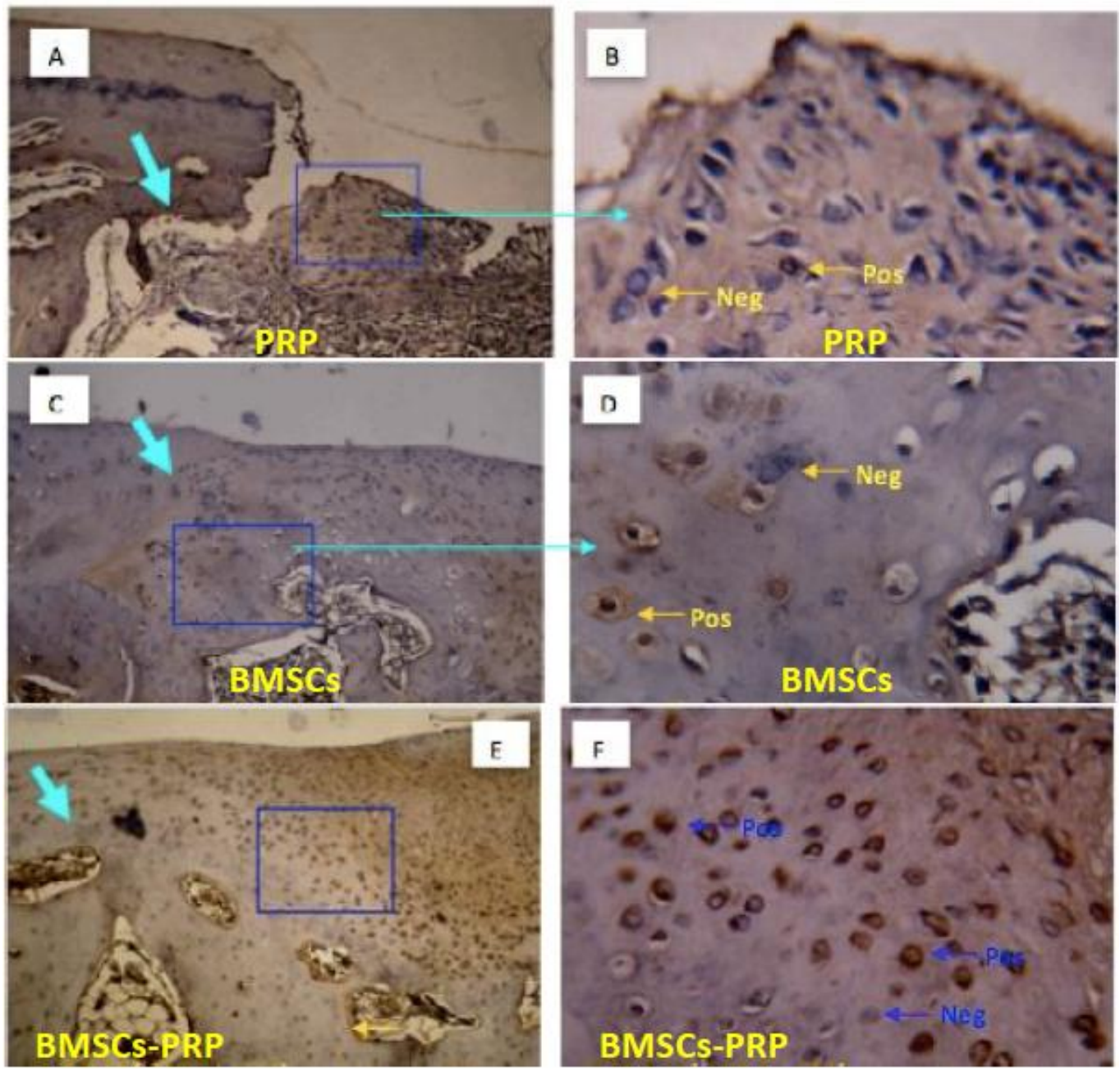

Figure 7 Total expression of Aggrecan chondroprogenitor cell defect joints

$A$ and B. Injection of PRP. Showed positive reaction to a brown color, not brown negative.arrows indicate cartilage growth boundary (kondrogenesis). (A, preparations no.8 and B. preparation no.5).

$\mathrm{C}$ and D. Injection BMSCs. Arrows indicate cartilage growth boundary (kondrogenesis) defect, which showed positive reaction to a brown color, notnegative.brown (Preparations no.12)

E and F. BMSCs-PRP injection. Arrows indicate cartilage growth boundary (kondrogenesis), which indicates a positive reaction in brown, brown negative.

The Agrecan immunohistochemical examination in the figure above shows the differences in the number and pattern of the Agrecan expression cell. The difference in numbers was seen in the agrecan expression of different cells between tissue matrices in each treatment group using x100 magnification. Based on the figure above, the number of
Agrecan expression cells is found more in the BMSCs-PRP group (Figure 5E) than in the PRP and BMSCs groups. Differences in the nuclear, nucleating, and nucleotide-aging cells of the Aggressive Aggressive expression of the nuclear enzyme in the X400 magnification. In the BMSCs-PRP group (Fig. 7F), the largest number of positive cells compared to the PRP 
group (Figure 5B) and BMSCs (Figure 7D)

\section{Number of collagen type 2 expression cells}

Table 4 shows the difference in the number of type 2 collagen expression cells, most in the

Table 4 Percentage of collagen type 2 treatment group PRP, BMSCs and BMSCs-PRP

\begin{tabular}{|c|c|c|c|c|c|c|}
\hline \multirow[b]{2}{*}{ Group } & \multirow{2}{*}{$\mathrm{N}$} & \multicolumn{4}{|c|}{ Arecan $(\%)$} & \multirow{2}{*}{$\begin{array}{l}\text { Brown- } \\
\text { Forsythe } \\
\text { Statistics }\end{array}$} \\
\hline & & $\overline{\mathrm{x}}$ & SD & Min & $\operatorname{Max}$ & \\
\hline PRP & 10 & $2,70^{\mathrm{a}}$ & 0,52 & 1,89 & 3,64 & \multirow{3}{*}{$\begin{array}{l}\text { Stat }=8.81 \\
\mathrm{p}=0.000 *\end{array}$} \\
\hline BMSCs & 11 & $8,07^{\mathrm{b}}$ & 1,41 & 5,64 & 10.02 & \\
\hline BMSCs & 11 & $18.58^{\mathrm{c}}$ & 1.07 & 16.87 & 20.02 & \\
\hline
\end{tabular}

Description: * significant at a $=0.05$

BMSCs-PRP group and at least in the PRP group. The number of cells in the BMSCs-PRP group was $18.58 \%$, while the PRP group was $2.70 \%$.

a, b, c different superscript indicate a difference between groups (based on multiple comparisons Games-Howell)

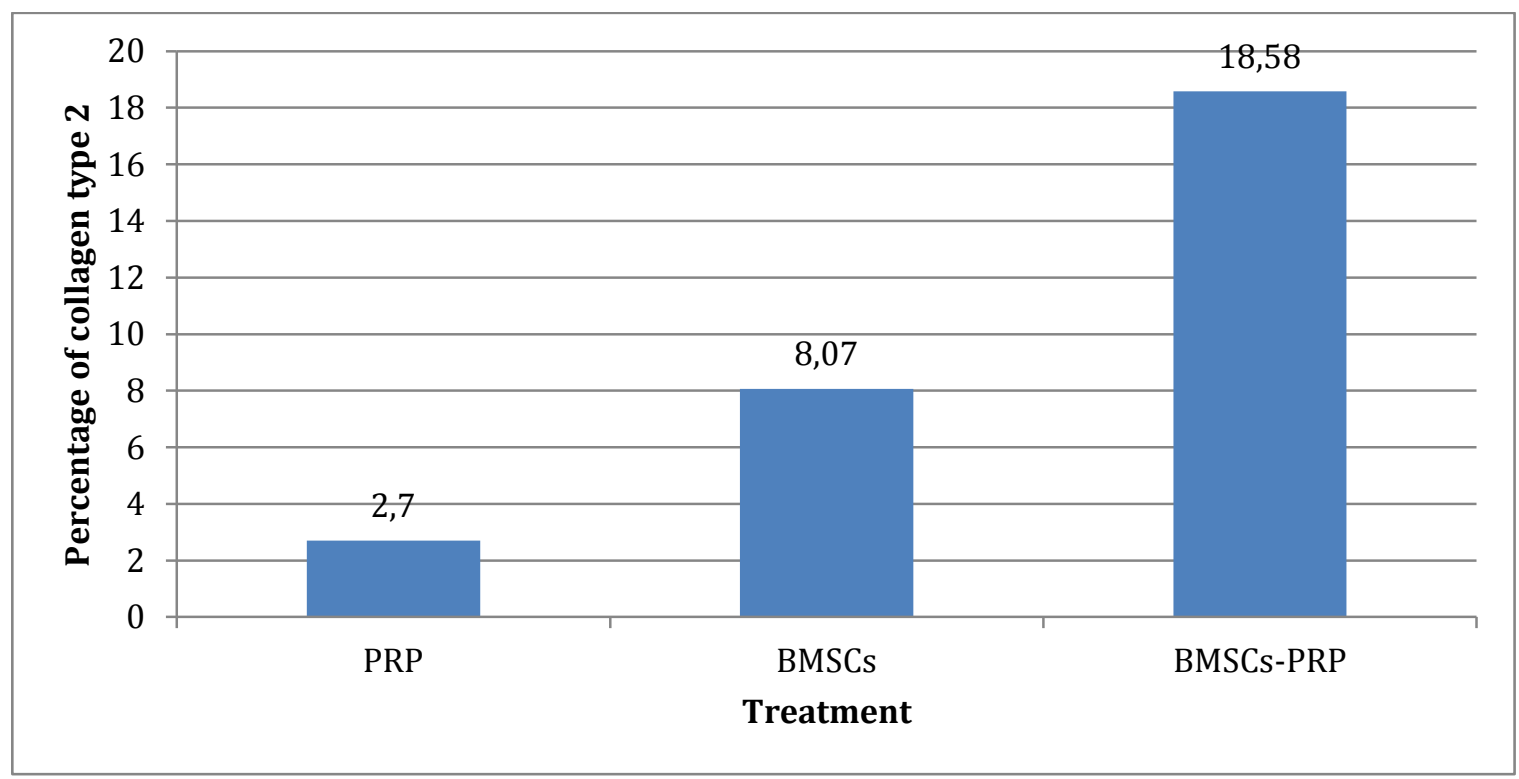

Figure 8 Comparison of type 2 collagen in the three treatment groups

Figure 8 presents the percentage of type 2 collagen in each treatment group. The results of analysis with Brown-Forsythe Statistic obtained $\mathrm{p}$ value $=0,000$ which means there is significant difference between the number of cells expression Collagen type 2 in the group PRP, BMSCs and BMSCs-PRP. 

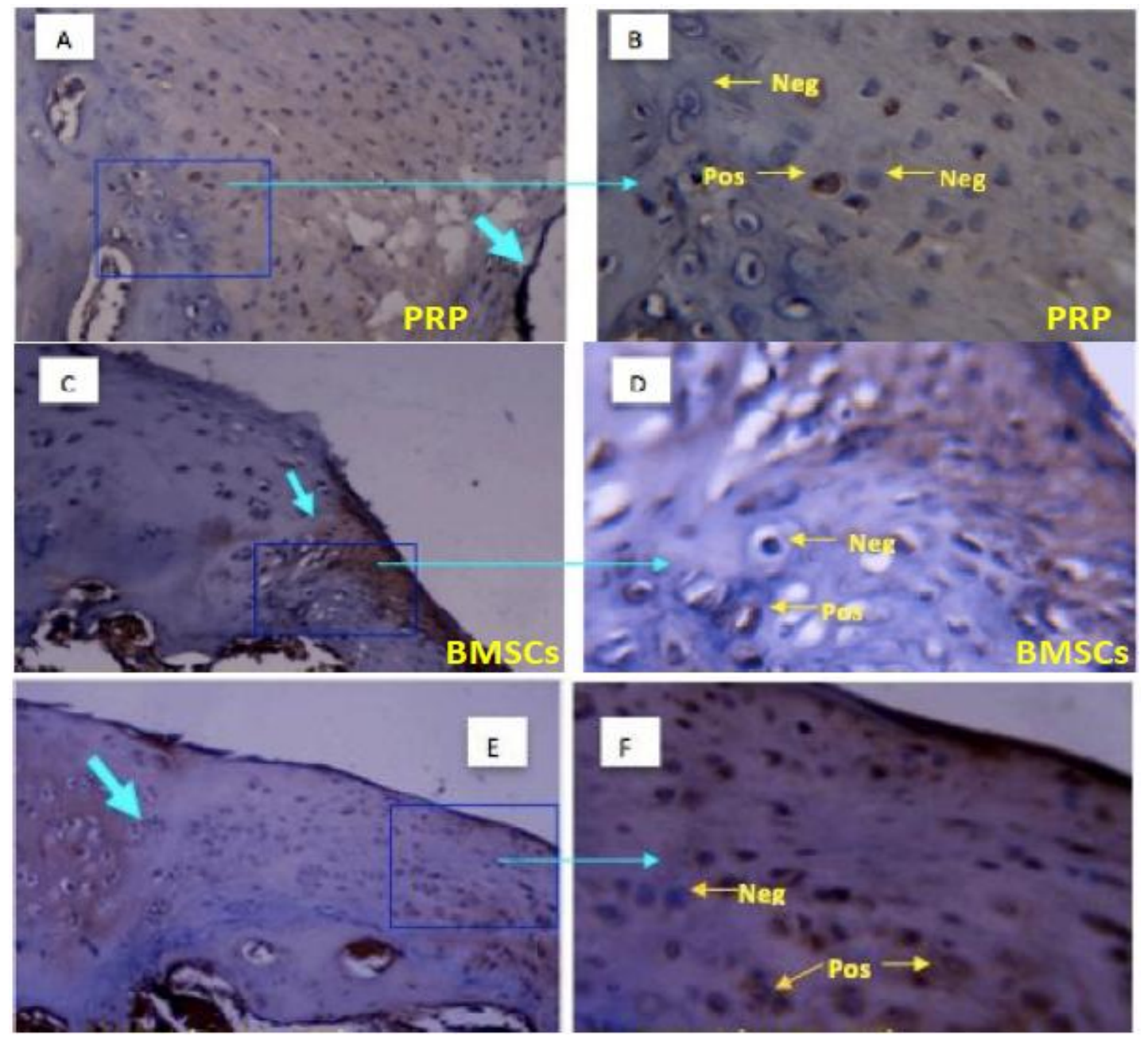

Figure 9 The number of cells condroprogenitorpengekspresi collagen type 2 defect joints

$\mathrm{A}$ and B. Injection of PRP. Showed positive reaction to brown, color less negative brown arrows indicate cartilage growth boundary (kondrogenesis). (Apreparation and B stocks no.8 no.5).

$\mathrm{C}$ and D. Injection BMSCs. Arrows indicate cartilage growth boundary (kondrogenesis) defect, which showed positive reaction to a brown color, notnegative. brown (Preparations no.12)

E and F. BMSCs-PRP injection. Arrows indicate cartilage growth boundary (kondrogenesis), which indicates a positive reaction in brown, brown negative.

Immunohistochemical examination Collagen type 2 in the figure above shows the difference in the number of collagen type 2 expression cells in each group. The amount difference can be seen in the network matrix in each treatment group using x100 magnification. The number of collagen type 2 expression cells was found more in the BMSCs-PRP group (Figure 5.5E) than in the PRP group (Figure 9A) and BMSCs (Figure 9C). At $\mathrm{x} 400$ magnification, each treatment group expresses a condroprogenitor cell. (Fig. 9B, D and F). 


\section{DISCUSSION}

\section{Platelet Rich Plasma as a scaffold on cartilage repair}

Platelet rich plasma (PRP) in this treatment serves as a scaffold because its 3-dimensional shape, it provide an environment suitable for BMSCs proliferation and differentiation. PRP application is now a rapidly growing method because it is able to provide growth factor easily, safely and effectively. This is evidenced in in vitro where PRP can increase the occurrence of proliferation and differentiation. PRP also plays an important role in the process of bone repair by stimulating migration, mitogenesis and differentiation into osteoblasts and angiogenesis. PRP acts as a vehicle for transport MSCs, so that it can be applied to the development of cartilage engineering techniques. In experiments with rabbits, it was found that subcutaneous PRP injection in seeding with chondrocytes could form tissues such as cartilage at in vivo. Minimal invasive PRP procedure can be applied to an irregular cartilage tissue by mixing the PRP fluid with the MSCs priorthe attachment to the defect (Lee KB, 2007).

In PRP the resulting platelet concentration varies depending on the method of manufacture employed. The effect of these various methods of manufacture on the efficacy of PRP is not clearly known. Differences in PRP products (centrifugation, platelet concentration and percentage between leucocytes and erythrocytes) may also be the reason for the difference in outcomes of various clinical applications.

This study used the procedure according to Rofi'i research (2013), where the process of centrifugation done 2 times with a speed of $3000 \mathrm{rpm}$ for 13 minutes at $1 \mathrm{st}$ and $3000 \mathrm{rpm}$ for 15 minutes in the second round. In another study, another commercial system was used in which leukocytes-PRP were classified according to DohanEhrenfest. In this system PRP produced with platelet concentration of about 220,000 platelets / $\mu$ l. Preparation of PRP consists of a stage where the poor platelet plasma (PPP) was not disposed. The advantage of this process is to avoid excessive manipulation that can lead to platelet stress in the second centrifuge, and avoid removing growth factors that depend on PPP. Another advantage is the closed circuit system in its purification process which causes the procedure to be safer. In this process usually after centrifugation of $8 \mathrm{ml}$ of peripheral blood, platelet recovery $>95 \%$ and recovery of leukocyte> 58\% (mononuclear cell recovery 93\%) in $4 \mathrm{ml}$ PRP. There are also other techniques which not activating PRP prior to injection (no trhrombin, $\mathrm{CaCl} 2$ ) added ,which may cause clot fibrin formation, since this activation will decrease the avaibility of platelets (Gobbi A, 2009).

Multiple growth factors either singly or in combination with cells have been applied to cartilage and demonstrated its ability to stimulate cell proliferation and the formation of matrix in tissue engineering. But there are some shortcomings such as short life span and expensive price. For that reason developed PRP application as the source of growth factor. Granul-á in PRP releases growth factors such as PDGF, TGF-â, VEGF and FGF. In addition, 
PRP if compared to whole blood (whole blood) contains PDGF with a concentration of 5.3 times. Contains TGF-dengan at a rate of 7.9 times and contains VEGF at 14.6 times. PRP therefore offers various advantages to accelerate the healing of cartilage obtained from the growth factor levels contained in platelets (Alsousou J, et al., 2009).

Currently, it is not clear whether the PRP effect on cell proliferation and cell differentiation is dependent on the dose of PRP or associated with growth factor concentrations. Various studies of PRP applications on tissues used differences in centrifugation, blood count, number of PRP obtained and growth factor concentrations contained therein (Weibrich G, et al., 2005).

The platelet count levels in this study may provide optimal benefits. The concentration of platelets in PRP did not differ greatly with the Anitua study, which obtained platelet concentration results of about 2.5 times normal. Other studies have shown that an excessively high platelet count can decrease the expected effect (paradoxsal effect). The dose-response relationship between platelet concentration and the stimulated biological process remains unclear. Once the growth factor reaches the targeted targeted receptor surface, the additional growth factor concentration has no effect. Growth factor will decrease the effect if the required upper (high) concentration limit is reached (Gobbi A and Bathan L, 2009).

\section{Differentiation of BMSCs into condroblasts on cartilage defects}

Bone marrow mesenchymal stem cells (BMSCs) show some potential for regenerating tissues. Ito S, et al., Reported in 2012 the results of transplantation of MSCs and hydroxyapatite in rat tibia bones without coculture. There was good bone formation and cell differentiation to osteoblast-like cells. This shows the osteogeniic potential of MSCs. In 2005 Izuta, et al., Examined the ability of MSCs through cultures in meniscus defects of experimental animals, proliferation of cells was obtained and the formation of extracellular matrices were numerous. This shows that BMSCs are an effective method for tissue regeneration (Izuta, et al., 2005; Ito S, et al., 2012).

Several studies have shown MSCs to cure cartilage defects through scaffold as carriers to collect MSCs at the site of the defect. Scaffold is currently widely studied is the use of hydrogel and fibrin-glue. In 2000 Wakitani S, et al. transplantation of MSCs attached to collagen gel on cartilage defects of rabbit joints. Histologic and Immunohistochemical healing results are obtained. This proves that BMSCs can differentiate into various derived cells depending on where they are transplanted (Wakitani S, 2000).

In another study Agung, et al., In 2005 injected BMSCs on the knee joint where ACL, meniscus and cartilage were injured. It was found that BMSCs can move towards tissues that are injured and differentiate into meniscus and cartilage which then synthesize the 
network matrix (Agung, et al., 2005).

Murphy, et al., In 2007 performed an injection of 1x107 MSCs cells in the animal model knee joints made by osteoarthritis by performing ACL and meniscus resection. Six weeks after the injection on observation found joint cartilage degeneration, remodeling osteophytes and subcondral sclerosis were milder than controls. These results are consistent with this study in terms of the contribution of BMSCs to injured tissue, although this study focuses more on acute trauma such as ACL injuries, meniscus and cartilage (Murphy, et al., 2003).

\section{Healing in cartilage defects with implantation of BMSCs - PRP}

This study, the best healing cartilage in MSCs injection group combined with PRP was obtained. Injection of BMSCs alone results in better cartilage cure than PRP ( $\mathrm{p}<0.05)$. This is seen from the amount of chondrocytes and cartilage area that formed after 10 weeks of treatment pemeberian. Immunohistochemical evaluation also showed that the formation of cartilagous tissue formed was clearly better in the BMSCs-PRP group.

The positive outcomes in this study differ from those of Wilke MM, et. all., 2007 using a combination of MSCs and fibrin matrices to correct defects in cartilage. In this study, MSCs in the fibrin matrix showed benefits obtained only in the initial phase. After 8 months evaluation there was no difference when compared with fibrin alone. In vitro studies found that there was a problem with migration and proliferation of MSCs when embedded with fibrin. In dilution as in this study will facilitate the proliferation and migration of MSCs to the site of the defect. PRP acts as a diluent liquid to facilitate the spread of MSCs in joints (Wilke MM, et al., 2007).

This study is in line with Kisiday, et.al., 2011 using Intra-articular Injectable MSCs with Hyaluronin (HA) directly into pig joints with partial thickness defects. Histologic and morphological evaluation performed after weeks 6 and 12 resulted in better cartilage recovery than controls (saline and HA solution). In another study to determine the ability of MSCs to improve repair cartilage, intra-articular injection of MSCs was done after microfraktur with drilling defek with 4 $\mathrm{mm}$ drill bit. The results showed that MSCs mixed with HA resulted in the best histological improvement (Kisiday, et al., 2011).

Intra-articular injection study of BMSCs on osteoarthritis raised by bone debris and cartilage from osteochondral fragments, there was a significant decrease in postaglandin levels in the synovium fluid. This effect is not found when an injection of MSCs is sourced from fat. In this study there was an increase of tumor necrosis factor (TNF) levels in the synovium fluid. The effects of BMSCs on cartilage improvement are derived from inhibition of catabolic effects and stimulation of anabolic effects through cytokine mediators.

A recent study on horse experimental animals for 2 to 5 years found that BMSCs produce protein core and chondroitin sulfate with longer chain and some shorter protein molecules than chondrocytes. This shows that 
BMSCs produce aggrecans with younger phenotype characteristics than those produced by chondrocytes. These results are in accordance with the results of this study where there is an increase in aggrecan content in defects given BMSCs (Kopesky PW, et al., 2010).

\section{Allogenic BMSCs}

Allogenic BMSCs are a new hope for healing cell-based cartilage. Allogenic BMSCs allow patients to be injected only once, no need for any 2 action for harvesting cells and implantation. This allogenic technique makes the treatment of defects in cartilage to be reliable, easy to apply and not invasive.

The concept of MSCs injection is based on the potential of MSCs to produce healing to cartilage defects with multiple pathways. MSCs are able to differentiate into target cells and populate new networks. In a previous study it was found that MSCs secrete various cytokines and growth factors that have autocrine and paracrine effects including local immune suppression, fibrosis inhibition and apoptosis in addition to mitotic stimulation and stem cell differentiation. The effect known as the trophic effect is different from the direct differentiation of MSCs into cartilage tissue. It is also demonstrated that mesenchymal stromal

\section{REFERENCES}

Aroen A, Loken S, Heir S, Alvik E, Ekeland A, Granlund O G, Engebretsen L. Articular Cartilage Lesions in 993 Consecutive Knee Arthroscopies.American Journal of cells present in the body can be reinforced by the paracrine effect of the MSCs themselves (Kaplan AI., 2006).

\section{CONCLUSION}

It is concluded that:

1. Intra-articular injections of allogenic bone marrow mesenchymal stem cells - platelet rich plasma (BMSCs-PRP) can increase the differentiation of BMSCs into condroblasts which produce agrecan and collagen type II on joint cartilage defect fullthickness.

2. Intra-articular injection of allogenic bone marrow mesenchylmal stem cell - rich plasma platelet (BMSCs - PRP) results in the formation of more aggressive and collagen type 2 expression cells than only injected BMSCs or PRP alone in fullthickness joint cartilage defects.

3. Intra-articular injection of allogenic bone marrow mesenchylmal stem cells - platelet rich plasma (BMSCs - PRP) results in the formation of more chondrocytes and cartilage area than those injected with only BMSCs or PRP alone in fullthickness joint cartilage defects.

4. Giving PRP is able to form a suitable environment for MSCs so that MSCs proliferate and differentiate into more condroblasts.

Sports Medicine, 2004 (32): 211-215.

Akeson W, Amiel D, Gershuni D. Articular cartilage physiology and metabolism. In: Resnick D, ed. Diagnosis of bone and joint disorders. Philadelphia: WB 
Saunders, 1994:23-1-23-31.

Athanasiou KA, Shah AR and Hernandez RJ. Basic Science of Articular Cartilage Repair. J. Clin Sport Me, 2002; 39(4):223 - 47.

Benninghoff A. Form und bau der Geleknorpel in ihren Bezeihungen zur Funktion. $Z$ Zellforsch Mikrosk Anat 2, 1925: 783825.

Buckwalter JA, Mankin HJ and Grodzinsky AJ. Articular cartilage and osteoarthritis. Instr Course Lect, 2005; 54: 465-80.

Bunnell BA, Kluge KA, Lee-Lin SQ, et al. Transplantation of transduced nonhuman primate CD34 cells using a gibbon ape leukemia virus vector: restricted expression of the gibbon ape leukemia virus receptor to a subset of CD34 cells. Gene Ther, 1999; 6: 48-56

Caplan AI, Dennis JE. Mesenchymal stem cells as trophic mediators. $J$ Cellular Biochem, 2006; 98: 1076-1084.

Caplan AI. Review: mesenchymal stem cells: cell-based reconstructive therapy in orthopedics. Tissue Eng, 2005; 11(7-8): 1198-211.

Chen FH, Song Li, Mauck RI and Li WJ. Mesenchymal Stem Cells. In:Lanza R, Langer R, Vacanti J eds. Principles of Tissue Engineering. $3^{\text {rd }}$ Edition.

Chen H, Sun J, Hoemann CD, et al. Drilling and microfracture lead to different bone structure and necrosis during bone-marrow stimulation for cartilage repair. J Orthop Res, 2009; 27(11): $\quad$ 1432-
8.

Clutterbuck AL, Asplin KE, Harris P, Allaway D, Mobasheri A. Targeting matrix metalloproteinases in inflammatory conditions. Curr Drug Targets, 2009; 10(12): 1245-54.

Cook SD, Barrack RL and Skinner HB. Basic Science in Orthopaedic Surgery, In Skinner HB, ed. Current Diagnosis and Treatment in Orthopaedics. $2^{\text {nd }}$ ed. New York: Lange Medical Book, 2000: 8 - 11 .

Darmadi SH. Mechanism of Cartilage Healing.Surabaya : Lab/SMF Orthopaedi dan Traumatologi FK Unair / RSUD Dr. Soetomo, 2002.

Gregory JS, Waarsing JH, Day J, Pols HA, Reijman M., Weinans $\mathrm{H}$ and Aspden RM. Early identification of radiographic osteoarthritis of the hip using an active shape model to quantify changes in bone morphometric features: can hip shape tell us anything about the progression of osteoarthritis? Arthritis Rheum, 2007; 56: 3634-3643.

Gobbi A and Bathan L. Biological Approach for Cartilage Repair.J Knee Surg, 2009; 2: $36-44$.

Gupta PK, Das AK, Chulikana A and Majumdar AS.(2012) Mesenchymal stem cells for cartilage repair in osteoarthritis. Stem cell \& Therapy. 3: 25 .

Henderson JH, Welter JF, Mansour JM, Niyibizi C, Caplan, A. I., and Dennis, J. E. Cartilage tissue engineering for laryngotracheal reconstruction: 
comparison of chondrocytes from three anatomic locations in the rabbit. Tissue Eng, 2007; 13(4): 843-53

Iliz MZ, Mok MT, Williamson OD, Campbell MA, Hughes CE, Handley CJ. Catabolism of aggrecan by explant cultures of human articular cartilage in the presence of retinoic acid. Arch Biochem Biophys, 1995: 322(1); 22-30.

Im GI, Kim DY, Shin JH, Hyun CW, Cho WH. Repair of cartilage defect in the rabbit with cultured mesenchymal stem cells from bone marrow. J Bone Joint Surg $B r, 2001 ; 83: 289-294$.

Khan WS, Adesida AB, Hardingham TE. Hypoxic conditions increase hypoxiainducible transcription factor 2alpha and enhance chondrogenesis in stem cells from the infrapatellar fat pad of osteoarthritis patients. Arthtitis research \& therapy, 2005; 9: R55.

Koga H, Engebretsen L, Brinchmann JE, Muneta $\mathrm{T}$ and Sekiya K. Mesenchymal stem cell-based therapy for cartilage repair: a review. 2009; 17: 1289 - 97.

Lewthwaite J, Blake S, Thompson RC, et al. Antifibrotic action of interleukin-1 receptor antagonist in lapine monoarticular arthritis. Ann Rheum Dis, 1995; 54: 591-596.

Magnussen RA, Dunn WR, Carey JL, Spindler KP. Treatment of focal articular cartilage defects in the knee: a systematic review. Clin Orthop Relat Res, 2008; 466: 952962.

Mankin HJ, Buckwaller JA, Grodzinsky AJ. Articular cartilage and osteoarthritis. Inst
Course Lect, 2005; 54: 465-480.

Muschler GF, Nakamoto C, Griffith LG. Engineering principles of clinical cellbased tissue engineering. $J$ Bone Joint Surg. Am., 2004: 86-A; 1541-1558.

McIlwraith CW, Frisbie DD, Rodkey WG, Kisiday JD, Werpy NM, Kawcak CE, Steadman JR. Evaluation of intraarticular mesenchymal stem cells to augment healing of microfractured chondral defects. Arthroscopy, 2011 Nov; 27(11): 1552-61.

Nejadnik H, Hui JH, Feng Choong EP, et al. Autologous bone marrow-derived mesenchymal stem cells versus autologous chondrocyte implantation: an observational cohort study. Am J Sports Med, 2010; 38: 1110-1116.

Punwar S, Khan WS. Mesenchymal Stem Cells and Articular Cartilage Repair: Clinical Studies and Future Direction. Open Orthop J, 2011; 5: 296-301

Redman SN, Oldfield SF and Archer CW. (2005) Current strategies for articular cartilage repair. Eur Cell Mater, 2005 Apr 14; 9: 23 - 32.

Rofi'i dan Dwikora NU.(2011) Optimal Consentrasion Platelet rich plasma and growth factor with varius sentrifugation technique.Tesis, UniversitasAirlangga.

Sato M, Uchida K, Nakajima H, Miyazaki T, Guerrero AR, Watanabe S, Roberts S, Baba H. Direct transplantation of mesenchymal stem cells into the knee joints of hartley strain guinea pigs with spontaneous osteoarthritis. Arthritis Res Ther, 2012; 14:R31. 
Sharma B, Williams CG, et al. Designing zonal organization into tissue-engineered cartilage. Tissue Eng, 2007; 13(2): 405414

Sun Y, Lu Y, Chen S, Prasad M, Wang X, Zhu Q, Zhang J, et al. Key proteolytic cleavage site and full-length form of DSPP. J Dent Res, 2010; 89: 498-503.

Wakitani S, Goto T, Pineda SJ, Young RG, Mansour JM, Caplan AI, Goldberg VM.
Mesenchymal cell-based repair of large, full-thickness defects of articular cartilage. J Bone Joint Surg Am, 1994; 76: 579-592.

Whitman DH, Berry RL, Green DM. Platelet gel: an autologous alternative to fibrin glue with applications in oral and maxillofacial surgery. J Oral Maxillofac Surg, 1997; 55(11): 1294-1299. 